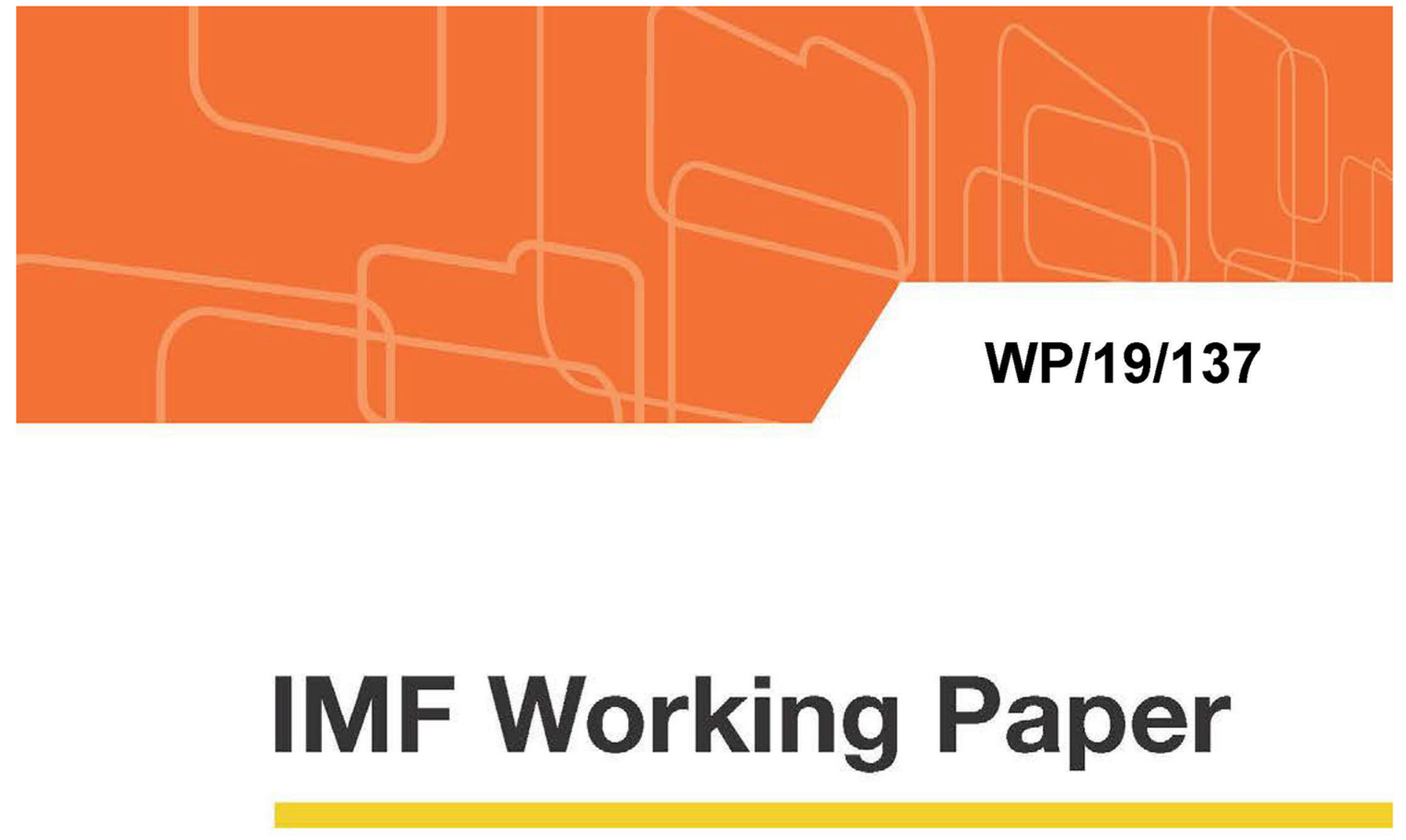

\title{
Productivity Drag from Small and Medium-Sized Enterprises in Japan
}

By Mariana Colacelli and Gee Hee Hong 


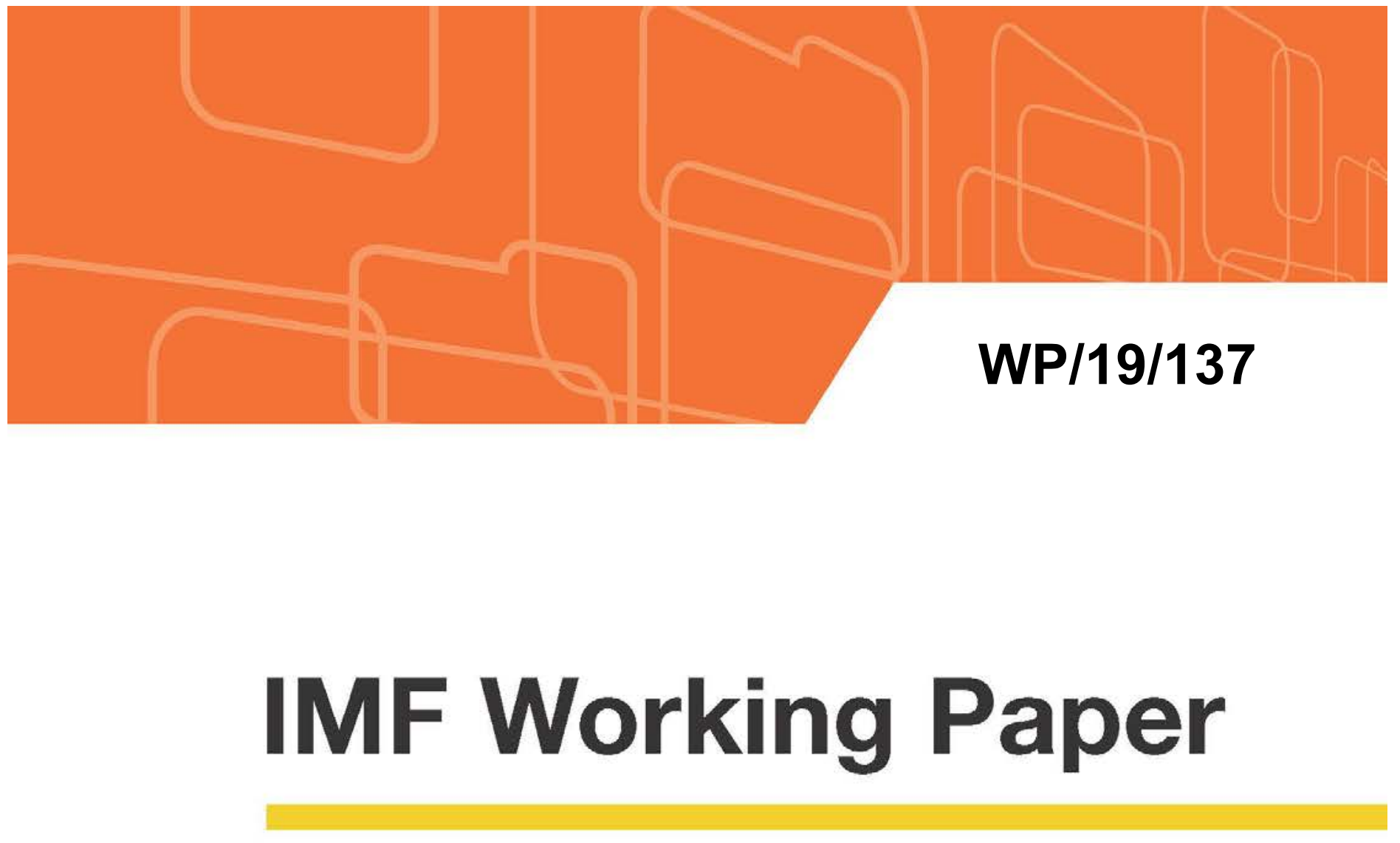

\section{Productivity Drag from Small and Medium-Sized Enterprises in Japan}

By Mariana Colacelli and Gee Hee Hong

I N T E R N A T I O N A L M O N E T A R Y F U N D 


\title{
IMF Working Paper
}

\author{
Asia Pacific Department
}

\section{Productivity Drag from Small and Medium-Sized Enterprises in Japan ${ }^{1}$}

\author{
Prepared by Mariana Colacelli and Gee Hee Hong \\ Authorized for distribution by Paul Cashin
}

June 2019

IMF Working Papers describe research in progress by the author(s) and are published to elicit comments and to encourage debate. The views expressed in IMF Working Papers are those of the author(s) and do not necessarily represent the views of the IMF, its Executive Board, or IMF management.

\begin{abstract}
Productivity growth in Japan, as in most advanced economies, has moderated. This paper finds supportive evidence for the important role of small and medium-sized enterprises (SMEs) in explaining Japan's modest productivity growth. Results show a substantial dispersion in firm-level productivity growth across sectors and even across firms within the same sector. SMEs, on average, exhibit lower productivity growth than non-SMEs in Japan, with smaller and older SMEs showing particularly low productivity growth. Estimates suggest that boosting productivity growth in all of the worst-performing SMEs could improve overall productivity growth by up to 1.8 percentage points. The SME credit guarantee system, SME financing constraints, demographic factors, and lack of intangible capital investment are discussed as contributors to the slow productivity growth of Japan's small and old SMEs.
\end{abstract}

JEL Classification Numbers: L1, O3, O4

Keywords: Productivity, Firm Dynamics, Small and Medium-Sized Enterprises, Intangible Investment

Authors’ E-Mail Addresses: mcolacelli@imf.org, ghong@imf.org

\footnotetext{
${ }^{1}$ The authors thank seminar participants at the Japanese Ministry of Finance, Masayuki Morikawa (RIETI), Paul Cashin, Naoko Miake, Kazuaki Miyachi, Cian Ruane, Todd Schneider, and Niklas Westelius for helpful comments. We thank Anh Van Le for excellent research assistance.
} 
Abstract

A. Introduction

B. Data Description and Summary Statistics

C. Productivity Growth among Japanese Firms

D. Japanese SMEs: Productivity Growth and Firm Characteristics

E. What Explains Low Productivity Growth among Japanese SMEs?

F. Conclusions and Policy Discussion

F. Conclusions and Policy Discussion

References

\section{Figures}

1. Productivity Growth in Major Advanced Economies (2000-16)

2. Distribution of Labor Productivity Growth, 2001-13: SMEs vs. non-SMEs

Tables

1. Comparison of Productivity and Productivity Growth Across Firms and Sectors, 2001-13 $\underline{6}$

2. Firm Characteristics and Productivity Growth, 2001-13

3. SMEs Intangible Investment and Productivity Growth, 2001-13 $\underline{10}$

\section{Appendices}

1. Descriptive Statistics 19

2. SME Definition

\section{Annexes}

1. Japan's Credit Guarantee Scheme $\underline{13}$

2. Policies to Promote Business Succession in Japan 


\section{A. Introduction}

Japan's productivity growth, as in most advanced economies, has moderated since the Global Financial Crisis (GFC) of 2007-08. Pre-crisis productivity growth for Japan averaged 0.8 and 1.6 percent per year as measured by multi-factor productivity and labor productivity, respectively. This is a modest performance when compared with some of its peers, including Germany, the United States and the United Kingdom (Figure 1). After the GFC, productivity growth decelerated for most countries by varying degrees (IMF, 2017a). While the slowdown in Japan has not been as pronounced as in some other countries such as the United Kingdom and the United States, average productivity growth has moderated.

Figure 1. Productivity Growth in Major Advanced Economies (2000-16)

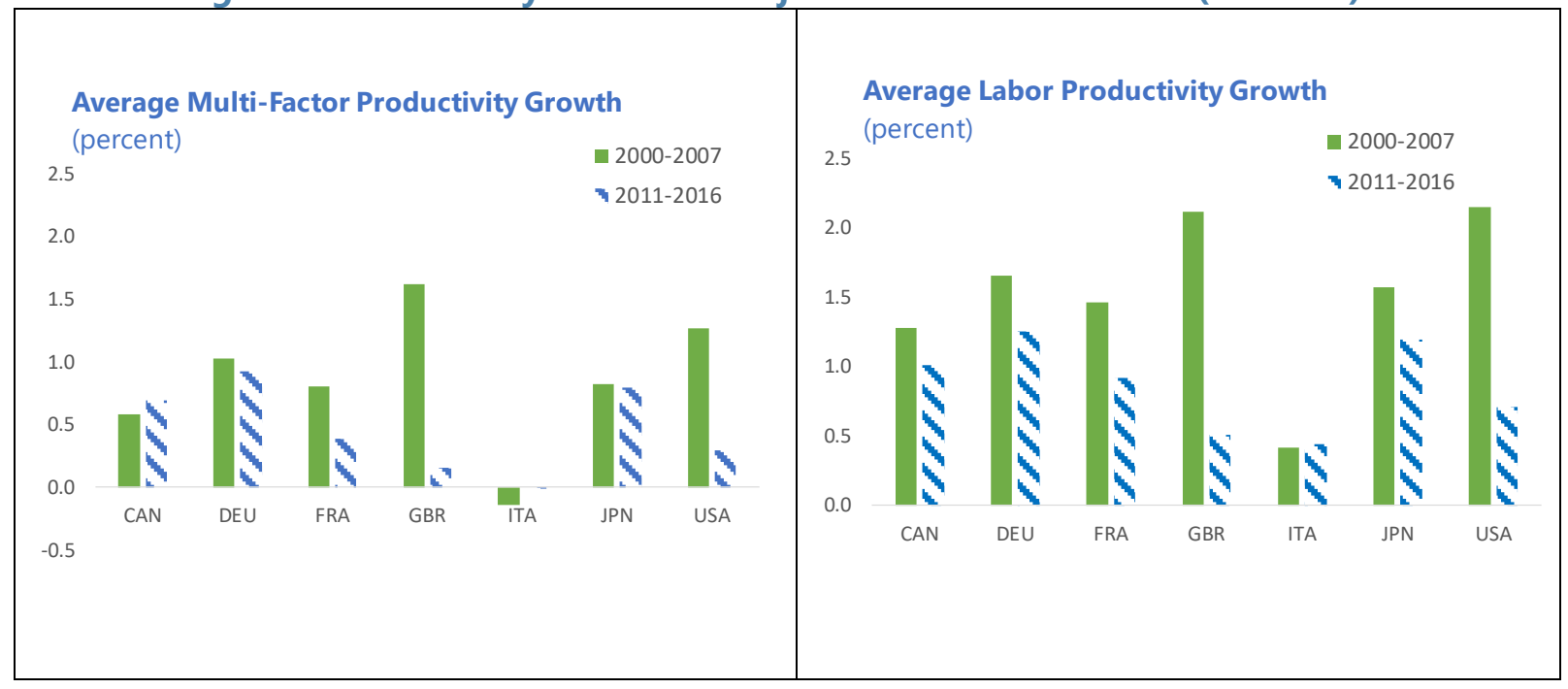

Source: OECD.

Note: Labor productivity growth is defined as the growth rate of output per capita.

Sluggish SME productivity growth is a drag on Japan's overall productivity growth. SME productivity growth has been significantly lower than that of large enterprises in Japan. According to Japan's Ministry of Finance, SME labor productivity growth has been flat for over a decade. ${ }^{2}$ By contrast, labor productivity of large enterprises in both manufacturing and non-manufacturing sectors has been improving since the GFC. Given the significance of SMEs in the Japanese economy-SMEs employ close to 70 percent of the total work forceboosting SME productivity growth would improve Japan's overall productivity growth. ${ }^{3}$

\section{This paper studies firm-level productivity growth in Japan, with a focus on SMEs and} potential explanations for their weak performance. Using a detailed firm-level dataset for Japan, the analysis investigates the following questions: (i) What stylized facts describe Japanese firms in terms of their productivity growth across and within sectors? (ii) What

\footnotetext{
${ }^{2}$ Financial Statements Statistics of Corporations by Industry, Ministry of Finance (2017).

${ }^{3}$ SMEs account for more than 50 percent of Japan's GDP in value-added terms in the manufacturing sector (Ministry of Economics, Trade and Industry, 2013).
} 
SME characteristics are associated with low productivity growth? (iii) What explains low productivity growth in Japanese SMEs? We consider several hypotheses to explain Japanese SME performance, including SME public credit guarantees, financing constraints, demographics, and investment in intangible capital.

This paper is structured as follows. Section B describes the main dataset used and provides summary statistics of key variables. Section C presents stylized facts on the distribution of productivity of Japanese firms across and within sectors. Section D discusses the relationship between SME characteristics and productivity growth. Section E looks at factors that potentially hamper SME productivity growth in Japan. The last section concludes with a policy discussion.

\section{B. Data Description and Summary Statistics}

Data and Sample. The main dataset used is ORBIS - a commercial database provided by Bureau van Dijk that includes firm-level financial information across countries (Gal 2013, Kalemli-Özcam et al. 2015). The sample extracted for Japan is comprised of an unbalanced panel of almost 2 million observations over the period 2001-13, covering over 400,000 unique firms sampled for an average of 5 years per firm. Most of the Japanese firms are unlisted with only about 2,000 of the included firms labeled as listed. Firms are categorized into 81 different 2-digit NACE (revision 2) industry code. We exclude observations that are in public administration and financial sectors. ${ }^{4}$

Definition and Sample Coverage of SMEs. We identify SMEs in ORBIS according to the definition provided by the "2018 White Paper on SMEs in Japan" by the Ministry of Economy, Trade and Industry (METI). METI has two criteria to define an SME: (i) size of capital; or (ii) number of employees per firm, with thresholds varying by sector. ${ }^{5}$ We use the number of employees as the main criteria, following the definition provided by METI. As a result, 93 percent of the observations in the ORBIS Japan sample are identified as SMEs.

Firm-level variables. Our main variable to study productivity is labor productivity, which is calculated as total revenue per number of employees in real terms. ${ }^{6}$ Labor productivity growth is the annual growth rate of labor productivity. The variable age records the age of each firm in number of years. A measure of total assets (in logs) is used to capture firm size. Investment is defined as the annual change in the stock of physical capital (measured by

\footnotetext{
${ }^{4}$ To create values in real terms, we use industry-level deflators from the OECD STAN database, after converting the data into national currency (see Gal and Hijzen, 2016, for more details). Outliers are excluded by trimming the top and bottom 1 percent of observations for the measures of employment growth, investment (both tangibles and intangibles), and labor productivity growth.

${ }^{5}$ For instance, for manufacturing firms, the SME threshold is $¥ 300$ million total capital or 300 employees, while for the service industry, the SME threshold is $¥ 50$ million total capital or 100 employees (see Appendix II for more details).

${ }^{6}$ For a sub-sample of firms with enough information to calculate total factor productivity, we find that total factor productivity is highly correlated with labor productivity.
} 
tangible fixed assets) as a share of total assets. We also use intangible investment (as a share of total investment) to study its potential role in productivity growth. ${ }^{7}$ On average, SMEs are younger than non-SMEs (30 vs. 42 years), they have fewer employees ( 21 vs. 250), and they have less assets than non-SMEs. A median SME invests less than a median non-SME in tangible fixed assets and invests a smaller share of intangible investment in total investment. One quarter of SMEs do not invest in intangible capital. Appendix I provides detailed descriptive summary statistics.

\section{Productivity Growth among Japanese Firms}

\section{Productivity growth is, on average, lower and more dispersed for SMEs than non-}

SMEs. Average annual labor productivity growth of non-SMEs is -1.0 percent over the sample period, higher than that of an average SME by 1 percentage point (Appendix I). Productivity growth is more dispersed for SMEs than non-SMEs as the standard deviation of SMEs is about 1.7 times higher than that of non-SMEs (Figure 2 and Appendix I). Results from a simple OLS regression show that an average SME firm has significantly lower annual productivity growth than non-SMEs (by 1.2 percentage points as shown in column (1), Table 1). The level of labor productivity is also significantly lower for SMEs (by about 0.5 percentage points).

Figure 2. Japan: Distribution of Labor Productivity Growth, 2001-13: SMEs vs. non-SMEs

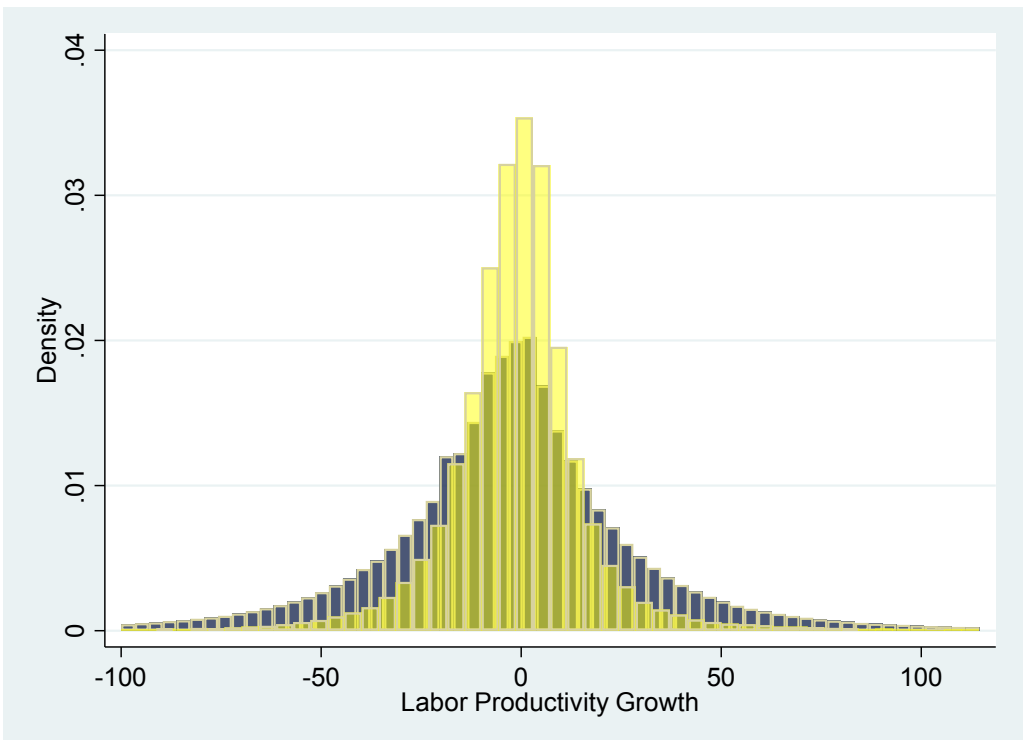

Note: Yellow bars show the distribution of labor productivity growth for non-SMEs. Grey bars show that of SMEs. Source: ORBIS; IMF staff calculations.

\footnotetext{
${ }^{7}$ Intangible investment is defined as the annual change in the stock of intangible capital, measured by intangible fixed assets such as formation expenses, research expenses, goodwill, development expenses and all other expenses with a long-term effect.
} 


\section{There is a positive productivity gap between manufacturing and non-manufacturing} firms. Columns (3) and (4) (Table 1) show that manufacturing firms have higher productivity growth and productivity level than non-manufacturing firms, when studying the full sample. ${ }^{8}$ Restricting the sample to SME firms, we find similar results where manufacturing firms have a 0.8 percentage point higher annual productivity growth than non-manufacturing firms and have a 0.1 percentage point higher productivity level (columns (5) and (6)).

Table 1. Japan: Comparison of Productivity and Productivity Growth Across Firms and Sectors, 2001-13

\begin{tabular}{|c|c|c|c|c|c|c|}
\hline & $\begin{array}{c}\text { (1) } \\
\text { Labor } \\
\text { Productivity } \\
\text { Growth }\end{array}$ & $\begin{array}{c}\text { (2) } \\
\text { Labor } \\
\text { Productivity }\end{array}$ & $\begin{array}{c}\text { (3) } \\
\text { Labor } \\
\text { Productivity } \\
\text { Growth }\end{array}$ & $\begin{array}{c}\text { (4) } \\
\text { Labor } \\
\text { Productivity }\end{array}$ & $\begin{array}{c}\quad(5) \\
\text { Labor } \\
\text { Productivity } \\
\text { Growth }\end{array}$ & $\begin{array}{c}\text { (6) } \\
\text { Labor } \\
\text { Productivity }\end{array}$ \\
\hline & \multicolumn{4}{|c|}{ Full Sample } & \multicolumn{2}{|c|}{ SMES } \\
\hline SME dummy & $\begin{array}{c}-1.187^{* \star *} \\
(0.087)\end{array}$ & $\begin{array}{c}-0.465^{\star * *} \\
(0.003)\end{array}$ & $\begin{array}{c}-1.181^{* * *} \\
(0.087)\end{array}$ & $\begin{array}{c}-0.464^{\star * *} \\
(0.003)\end{array}$ & & \\
\hline $\begin{array}{l}\text { Manufacturing } \\
\text { dummy }\end{array}$ & & & $\begin{array}{c}0.821^{* * *} \\
(0.061)\end{array}$ & $\begin{array}{c}0.161^{\star * *} \\
(0.002)\end{array}$ & $\begin{array}{c}0.815^{\star * \star} \\
(0.065)\end{array}$ & $\begin{array}{c}0.137^{* \star *} \\
(0.002)\end{array}$ \\
\hline Constant & $\begin{array}{c}-0.660^{\star * *} \\
(0.123)\end{array}$ & $\begin{array}{c}13.243^{* * *} \\
(0.004)\end{array}$ & $\begin{array}{c}-0.834^{\star \star \star} \\
(0.124)\end{array}$ & $\begin{array}{c}13.209^{* * *} \\
(0.004)\end{array}$ & $\begin{array}{c}-2.004^{\star * *} \\
(0.101)\end{array}$ & $\begin{array}{c}12.774^{* * *} \\
(0.003)\end{array}$ \\
\hline Year FE & $\mathrm{Y}$ & $\mathrm{Y}$ & $\mathrm{Y}$ & $\mathrm{Y}$ & $\mathrm{Y}$ & $\mathrm{Y}$ \\
\hline Observations & $1,919,104$ & $1,919,104$ & $1,919,104$ & $1,919,104$ & $1,795,836$ & $1,795,836$ \\
\hline R-squared & 0.013 & 0.109 & 0.013 & 0.112 & 0.012 & 0.108 \\
\hline
\end{tabular}

Note: Standard errors in parentheses, ${ }^{* * *} p<0.01,{ }^{* *} p<0.05,{ }^{*} p<0.1$.

\section{Japanese SMEs: Productivity Growth and Firm Characteristics}

Previous studies find evidence that certain firm characteristics are associated with higher productivity growth. Empirical studies covering various countries find that younger firms tend to be more innovative and create more jobs, growing faster than older firms (Heshmati, 2001; Calvo, 2006; Haltiwanger et al., 2010; Lopez-Garcia and Puente, 2011). Among younger firms, particularly rapid productivity growth is observed for surviving young businesses (Haltiwanger, 2012). Other studies point to a positive correlation between firm size and productivity growthfor example, with larger firms taking advantage of increasing returns to scale associated with R\&D (Pagano and Schivardi, 2003). Linking age and size, Hsieh and Klenow (2014) focus on firms' life cycle dynamics where higher firm growth, for given age, is associated with higher productivity in the U.S. relative to Mexico and India.

In line with previous findings, regression analysis shows that smaller and older Japanese SMEs have lower productivity growth. A panel regression with sector and year fixed-effects shows that productivity growth is negatively associated with age and positively associated with firm size in Japan (Table 2). As firms age by ten years, annual labor productivity growth is lower by 0.6 percentage points, while a decrease in the size of total assets by 50 percent leads to 0.3 percentage points lower annual labor productivity growth (column (1)). Results in column (2) suggest these relationships to be non-linear: (i) while a firm's age is negatively correlated with

\footnotetext{
${ }^{8}$ Manufacturing dummy is set equal to one for sectors with NACE 2-digit code 10 to 33.
} 
labor productivity growth, its quadratic term is positive, suggesting that the negative impact of a firm's age on labor productivity growth decreases for older firms; and (ii) the positive impact of firm size on labor productivity growth decreases for larger firms. Results in column (3) suggest that the negative effect of age on productivity only applies to SMEs, while size is correlated with productivity growth for both SMEs and non-SMEs with a larger effect observed for SMEs.

\section{Small and old SMEs also tend to be 'laggards' (i.e. firms with persistently low productivity} growth). We define a firm to be a 'laggard' when it shows two consecutive years of productivity growth in the bottom $10^{\text {th }}$ percentile. ${ }^{9}$ According to this definition, almost 11,000 unique firms in our sample are laggards (and 99 percent of them are SMEs). Our baseline specification is a probit regression which estimates the likelihood of a firm being a laggard. Column (4) in Table 2 shows that smaller SMEs have a higher likelihood of becoming a laggard. The significant negative coefficient on the quadratic term on age in column (5) shows that while older SMEs are more likely to be a laggard, the impact of age on the probability of being laggard becomes weaker as the SME gets older. For size, we do not find such non-linearity on the probability of being a laggard among SMEs.

Table 2. Japan: Firm Characteristics and Productivity Growth, 2001-13

\begin{tabular}{|c|c|c|c|c|c|}
\hline & \multicolumn{3}{|c|}{ Labor Productivity Growth } & \multicolumn{2}{|c|}{$\begin{array}{c}\text { Probability of Being a } \\
\text { Laggard Firm }\end{array}$} \\
\hline & (1) & $(2)$ & (3) & (4) & $(5)$ \\
\hline & \multicolumn{3}{|c|}{ Full Sample } & \multicolumn{2}{|c|}{ SMEs } \\
\hline Age & $\begin{array}{c}-0.056^{\star * \star} \\
(0.000)\end{array}$ & $\begin{array}{c}-0.227^{* * *} \\
(0.006)\end{array}$ & $\begin{array}{c}0.003 \\
(0.006)\end{array}$ & $\begin{array}{r}0.000 \\
(0.000)\end{array}$ & $\begin{array}{l}0.003^{* * *} \\
(0.000)\end{array}$ \\
\hline Size & $\begin{array}{l}0.671^{* * *} \\
(0.000)\end{array}$ & $\begin{array}{c}2.484^{\star * *} \\
(0.119)\end{array}$ & $\begin{array}{l}0.565^{\star * *} \\
(0.021)\end{array}$ & $\begin{array}{c}-0.099 * * * \\
(0.001)\end{array}$ & $\begin{array}{c}-0.111 * * * \\
(0.011)\end{array}$ \\
\hline $\mathrm{Age}^{\wedge} 2$ & & $\begin{array}{l}0.003^{* * *} \\
(0.000)\end{array}$ & & & $\begin{array}{c}-0.000 * * * \\
(0.000)\end{array}$ \\
\hline Size^2 & & $\begin{array}{c}-0.060 * * * \\
(0.004)\end{array}$ & & & $\begin{array}{c}0.001 \\
(0.000)\end{array}$ \\
\hline Age*SME dummy & & & $\begin{array}{c}-0.064^{* * *} \\
(0.006)\end{array}$ & & \\
\hline Size*SME dummy & & & $\begin{array}{c}0.240^{* * *} \\
(0.016)\end{array}$ & & \\
\hline Constant & $\begin{array}{c}-12.506^{* * *} \\
(0.013)\end{array}$ & $\begin{array}{c}-23.201^{* * *} \\
(1.017)\end{array}$ & $\begin{array}{c}-13.965^{* * *} \\
(0.581)\end{array}$ & $\begin{array}{c}-0.456^{\star * *} \\
(0.026)\end{array}$ & $\begin{array}{l}0.2632^{* * *} \\
(0.079)\end{array}$ \\
\hline Sector FE & $\mathrm{Y}$ & $\mathrm{Y}$ & $\mathrm{Y}$ & $\mathrm{Y}$ & Y \\
\hline Time FE & Y & Y & Y & Y & Y \\
\hline Observations & $1,273,583$ & $1,273,583$ & $1,273,583$ & $1,185,411$ & $1,185,411$ \\
\hline R-squared & 0.013 & 0.018 & 0.018 & 0.0435 & 0.0436 \\
\hline
\end{tabular}

Note: Size is log of total assets. Age records the age of the firm in number of years. Laggard firm is defined as a firm with productivity growth in the bottom $10^{\text {th }}$ percentile for two consecutive years. Standard errors in parentheses, ${ }^{* *} p<0.01,{ }^{* *} p<0.05,{ }^{*} p<0.1$. R-squared reported for probit regressions are pseudo R-squares.

\footnotetext{
${ }^{9}$ OECD (2017) coined the term 'laggard' to refer to firms with productivity performance in the bottom $10^{\text {th }}$ percentile of their cohort. We modify this definition to capture firms with two consecutive years of productivity performance in the bottom $10^{\text {th }}$ percentile to focus on firms that persistently drag overall productivity growth.
} 


\section{Estimates suggest that boosting the performance of all laggard SMEs (to that of an average Japanese firm that is not a laggard SME) could improve overall annual firm productivity growth by about 1.8 percentage points. Under the extreme assumption that} labor productivity growth of all laggard SMEs reaches that of the average firm in the rest of the sample, we estimate a 1.8 percentage point increase in productivity growth using the weighted average for annual firm-level labor productivity growth increases (where observations are weighted by firm revenue). The assumed boost in laggard SMEs' productivity growth provides a benchmark for an upper bound on the impact from successful reform of the SME sector. While the unweighted average firm-level labor productivity growth is -1.98 percent in our sample (Appendix I, "All" sample), the weighted average is 0.3 percent (as low productivity growth firms have lower revenue as well). Under the extreme assumption described, the weighted average of annual firm-level labor productivity growth is boosted by 1.8 percent (from 0.3 to 2.2 percent). ${ }^{10,11}$

\section{E. What Explains Low Productivity Growth among Japanese SMEs?}

In this section, we explore potential explanations for our findings. Why are SMEs, particularly small and old ones, less productive than non-SMEs? Various factors are likely at play. First, the overly generous $S M E$ credit guarantee system in Japan, reduces the incentives for non-viable SMEs to exit, and contributes to the survival of unproductive, small and old SMEs. Second, SME financing constraints prevent them from investing, including in productivity-enhancing and often high-risk projects, such as intangible investment. Finally, demographic factors also play a role: SME business manager succession is hampered due to a shrinking and ageing population, while dim demand prospects lower SME incentives to invest in long-term productivity gains.

Japan has an overly generous SME credit guarantee system. The SME credit guarantee program in Japan was introduced in 1950 and is one of the key pillars of the government's SME support framework. The program is designed to enable SMEs to access finance and provides government-backed guarantees in case SMEs go into bankruptcy. ${ }^{12}$ The coverage of the largest SME credit guarantee scheme (Safety Net Program No. 5) was reduced from full

\footnotetext{
${ }^{10}$ Performing the same calculation, but using unweighted averages instead, we estimate that the average annual firm-level labor productivity growth improves by 6 percentage points - from -1.98 percent (as shown in Appendix I, "All” sample) to 4.04 percent.

${ }^{11}$ Colacelli and Fernandez-Corugedo (2018) use alternative estimates (by Lam and Shin, 2012 and IMF 2012 and 2013) suggesting a 2.5 percent increase in overall productivity (TFP) after ten years from the restructuring of the SME sector in Japan (where the productivity of smaller firms reaches about 80 percent of that of large firms), which delivers a 0.2 percentage point boost to GDP growth for 10 years. This alternative and more conservative result is based on the Credit Risk Database covering Japanese SMEs (i.e. not ORBIS data as used in the present paper).

${ }^{12}$ Forbearance lending in the 1990s led to the emergence of zombie firms and prevented non-viable firms from exiting, leading to a serious resource misallocation, dragging productivity growth (Caballero et al. 2008).
} 
coverage (100 percent) to partial coverage (80 percent) in April 2018, but still remains high (see Annex 1 for more details on Japan's credit guarantee scheme). ${ }^{13}$

SME guarantees are a likely contributor to Japan's low firm exit rates and misallocation of resources. Firms' exit and entry, the so-called 'firm dynamism' is key to productivity growth as it leads to an efficient allocation of resources (Haltiwanger et al. 2013, IMF 2018a). Historically, for Japan, firms' exit rate has been lower than in other advanced countries such as the U.K. and the U.S. Annual firms' exit rates were below 4 percent in 2016 in Japan (well below the target of 10 percent under Japan's Revitalization Strategy). The low exit rate of non-viable SMEs hampers aggregate productivity growth both by dragging productivity down and by preventing resources from being allocated to healthier existing firms and to potential entrants with higher productivity. ${ }^{14}$

\title{
Generous SME guarantees also discourage small firms from growing as it can lead to
} losing the benefits associated with SME status. For instance, Tsuruta (2016) shows that the SME decision to raise capital hinges crucially on the threshold capital level used to define an SME, and not necessarily on the quality of the projects. According to his study, firms with capital below the threshold level were significantly less likely to increase capital than firms above it, as they desired to maintain their SME status. Once the limit on capital in the definition of SMEs was raised in 1999, firms closer to the previous limit (¥100 million) increased their capital by more than those who had more capital than the limit and those who had capital much lower than the limit. ${ }^{15}$

\begin{abstract}
About a third of SMEs might face financing constraints that discourage investment, particularly investment in intangible capital. The IMF's Financial Sector Assessment Program report (IMF, 2017b) pointed out that the lending practices to SMEs in Japan complicate borrowing by small firms with growth potential. In particular, SMEs are at a disadvantage because lending remains largely based on fixed-asset collateral and personal guarantees, despite the existence of a credit bureau - and evidence suggests that about a third of SMEs might face financing constraints. The resulting difficulty in advancing investment projects particularly affects intangible capital which tends to be riskier. Alternative forms of finance for SMEs and startups — asset-based lending (ABL) and venture capital (VC) — have grown in Japan, but from very low levels, and still face important challenges.
\end{abstract}

\footnotetext{
13 Today, out of approximately $¥ 250$ trillion in loans outstanding to SMEs, those covered by credit guarantees account for more than 10 percent (IMF, 2017b).

${ }^{14}$ In fact, expanding our ORBIS sample to other countries, we find that the median age of Japanese SMEs for a given year (2014) is higher than that of most other countries (except Germany) with 35 years for entire sample, and 40 and 32 years for manufacturing and services sector, respectively.

${ }^{15}$ From a cross-country perspective, Japanese firms tend to be relatively small in our expanded ORBIS sample, as the median size of mature firms (more than 10 years old) is 14 employees per firm for manufacturing sector and 8 employees for services sector. This is lower than mature firms in other countries such as the United States, who employ about 23 persons in manufacturing and 16 in service sector. Criscuolo et al. (2014) and OECD (2017) document similar findings using a different data set.
} 


\section{Productivity growth of Japanese SMEs is positively correlated with investment in intangible capital. A growing body of literature shows that intangible assets, such as} research and development, are a driver of productivity growth (Corrado and others, 2013 and 2016; Duval et al. 2017). ${ }^{16}$ A panel regression analysis shows evidence in support of the role of intangible capital among Japanese SMEs. That is, SMEs with a higher share of intangible investment tend to have higher productivity growth. Columns (1) to (3) in Table 3 show that, even when controlling for previously determined firm characteristics associated with productivity growth in Japan (i.e. age and size), there is a positive relationship between intangible capital investment and productivity growth. Column (4) controls for the investment rate and the results hold.

Table 3. Japan: SMEs Intangible Investment and Productivity Growth, 2001-13

\begin{tabular}{|c|c|c|c|c|}
\hline & & SMEs Labor & tivity Growt & \\
\hline & $(1)$ & (2) & (3) & $(4)$ \\
\hline Age & $-0.021^{* * *}$ & & $-0.051^{* * *}$ & $-0.052^{* * *}$ \\
\hline & $(0.002)$ & & $(0.002)$ & $(0.002)$ \\
\hline Size & & $0.485^{* * *}$ & $0.676^{* * *}$ & $0.683^{* * *}$ \\
\hline & & $(0.015)$ & $(0.018)$ & $(0.018)$ \\
\hline Intangibles share (lag) & $0.009 * * *$ & $0.013^{* * *}$ & $0.007^{* * *}$ & $0.011^{* * *}$ \\
\hline & $(0.003)$ & $(0.002)$ & $(0.003)$ & $(0.003)$ \\
\hline Investment (lag) & & & & $0.006^{* \star *}$ \\
\hline & & & & $(0.001)$ \\
\hline Constant & $-5.710^{\star * *}$ & $-13.408^{* * *}$ & $-14.577^{\star \star *}$ & $-14.951^{\star * *}$ \\
\hline & $(0.722)$ & $(0.685)$ & $(0.760)$ & $(0.763)$ \\
\hline Observations & $1,121,618$ & $1,121,618$ & $1,121,618$ & $1,121,618$ \\
\hline R-squared & 0.016 & 0.016 & 0.017 & 0.017 \\
\hline
\end{tabular}

Note: Intangibles share is the share of intangible investment to total investment. Investment is the ratio of annual change in the stock of physical capital (measured by tangible fixed assets) over total assets. Standard errors in parentheses ${ }^{* \star *} p<0.01,{ }^{* \star} p<0.05,{ }^{*} p<0.1$.

\section{Demographic headwinds are also at play, as smooth succession of business managers is increasingly difficult and growth prospects are weak. There can be several channels} through which demographic headwinds can adversely affect managers' incentives to invest in productivity-enhancing investment. ${ }^{17}$ First, difficulties in finding suitable successors as business managers pose a risk to the continuation of any given business (Annex 2). Bank of Japan's "Regional Economic Report" (June 2018) shows that firms in services, construction and real estate are most affected by succession issues in business management. Relatedly, the exit of enterprises with sound financial health has hit record highs (nearly 30,000 in 2016,

\footnotetext{
${ }^{16}$ Using a broad classification of intangibles, Corrado et al. (2016) find that intangible capital deepening accounted for as much as 30 percent of labor productivity growth on average for Europe and the U.S. between 2000 and 2013.

${ }^{17}$ Reflective of the impact of demographic change on SMEs, the median age of Japanese SME owners has increased from 45-54 in 1995 to 65-69 in 2015 (Bank of Japan's Regional Economic Report, June 2018).
} 
according to METI, 2017), as retiring managers could not find a suitable heir. ${ }^{18}$ In addition, pessimistic growth prospects with shrinking domestic demand also reduce firms' incentives to invest further in highly productive investment such as R\&D investment, IT-related technology, and intangible investment in general as it usually has longer gestation periods. ${ }^{19}$

\section{F. Conclusions and Policy Discussion}

Enhancing SME productivity would improve Japan's aggregate productivity growth. SME productivity growth has been significantly weaker than that of large enterprises in Japan. Given the significant role of SMEs in the Japanese economy, boosting their productivity growth would improve Japan's overall productivity growth.

Empirical results show that Japan's SMEs exhibit lower productivity growth than nonSMEs, with smaller and older SMEs showing particularly weak performance. The analysis shows significant dispersion in firm-level productivity growth across sectors and also across firms within sectors. SMEs, on average, exhibit low productivity growth compared to non-SMEs (by about 1 percentage point per year), with smaller and older SMEs exhibiting particularly low productivity growth.

Several hypotheses were explored as potential explanations for the findings. The role of the SME credit guarantee system, SME financing constraints, demographic factors affecting managerial succession and business prospects, and lack of intangible investment, were discussed as contributors to the sluggish productivity growth of small and old SMEs.

Policies to facilitate exit of non-viable firms should be strengthened to promote efficient resource allocation, productivity growth, and to prevent firms' moral hazard (IMF, 2018b). Overly generous credit guarantee schemes prevent efficient resource allocations by reducing exit incentives of non-viable firms (Jones and Jin, 2017). Recent reforms of the SME credit guarantee system are a step in the right direction as they are expected to further encourage remaining non-viable firms to exit. However, overly generous coverage of credit guarantees should be further decreased to levels more in line with other OECD countries.

To alleviate SME financing constraints, banks should continue to upgrade their riskassessment capacities, and other SME financing should be encouraged. Reiterating the recommendations from the IMF's Financial Sector Assessment Program (2017b), banks

\footnotetext{
${ }^{18}$ In April 2016, the Act for the Partial Revision of the Act on Facilitation of Succession of Management of Small and Medium Sized Enterprises came into effect to promote smooth business succession. The act stipulated smooth transition by expanding the scope of inheritance rights concerning the reserved portion to non-relatives and measures for increasing the amount of mutual aid funding for business succession. This is relevant in light of the increasing business inheritance to non-family members in Japan (amounting to 40 percent in 2017, while only being 10 percent two decades ago).

${ }^{19}$ Firms that have a vision for long-term growth are more likely to invest in intangible capital (Zhou, 2016, for instance), as the return on intangible capital investment is highly uncertain and it has a longer gestation period than that of tangible capital.
} 
should continue to be encouraged to upgrade their credit risk-assessment capacities by making greater use of IT and enhancing staff skills, while reducing SME reliance on collateral and personal guarantees. Alternative forms of financing for SMEs and start-ups with financing constraints, such as asset-backed lending and venture capital, could be further promoted.

In the face of severe demographic headwinds, efforts to guarantee the smooth succession of business managers should be advanced and targeted to firms with greater potential. A Five-Year Plan for Business Succession formulated by the Japanese Small and Medium-Sized Enterprise Agency (SMEA) in 2017 is a step in the right direction. The Plan encourages smooth managerial succession by: raising awareness of the issue; strengthening the system to match business owners and successors; improving management of human resources; and encouraging sales and merger and acquisition of enterprises. However, the pro-succession efforts should be targeted to healthy firms with greater growth prospects.

\section{More broadly, additional training and education would help encourage} entrepreneurship, innovation and productivity growth. Closer collaboration between universities and SMEs on R\&D activities could help promote entrepreneurship and innovative activities. In addition, improvements in education and training would enhance human capital formation and productivity. 


\section{Annex 1. Japan's Credit Guarantee Scheme}

Japan is one offew countries that has been covering up to 100 percent of loans extended to SMEs under the public credit guarantee system (OECD, 2010). However, in April 2018, reforms to the credit guarantee system were implemented, which reduced the coverage of credit guarantees from 100 percent to 80 percent for non-emergency related loans (i.e. Safety Net Program No. 5). This Annex summarizes the history of credit guarantee schemes in Japan and outlines the main features of recent reforms.

Credit Guarantee System in Japan. Japan's public credit guarantee program is mostly used by SMEs, with about 10 percent of total outstanding loans to SMEs ( $¥ 29$ trillion out of $¥ 258$ trillion) covered under the credit guarantee scheme (Japan Finance Corporation, 2017). When firms request loans from financial institutions, it is common for financial institutions to ask SMEs to apply for credit guarantee from Credit Guarantee Corporations (hereafter, CGCs). After the CGCs agree to offer guarantees to the loans, bank loans are extended to firms. In case of default, lender banks ask the CGCs to compensate for the losses incurred, up to the coverage allowed by the credit guarantee system. The funding used by the CGCs to compensate the losses is provided by both the Japanese government and local governments through subsidies, direct contributions and insurance via the Japan Finance Corporation (JFC) (see Figure below for more details).

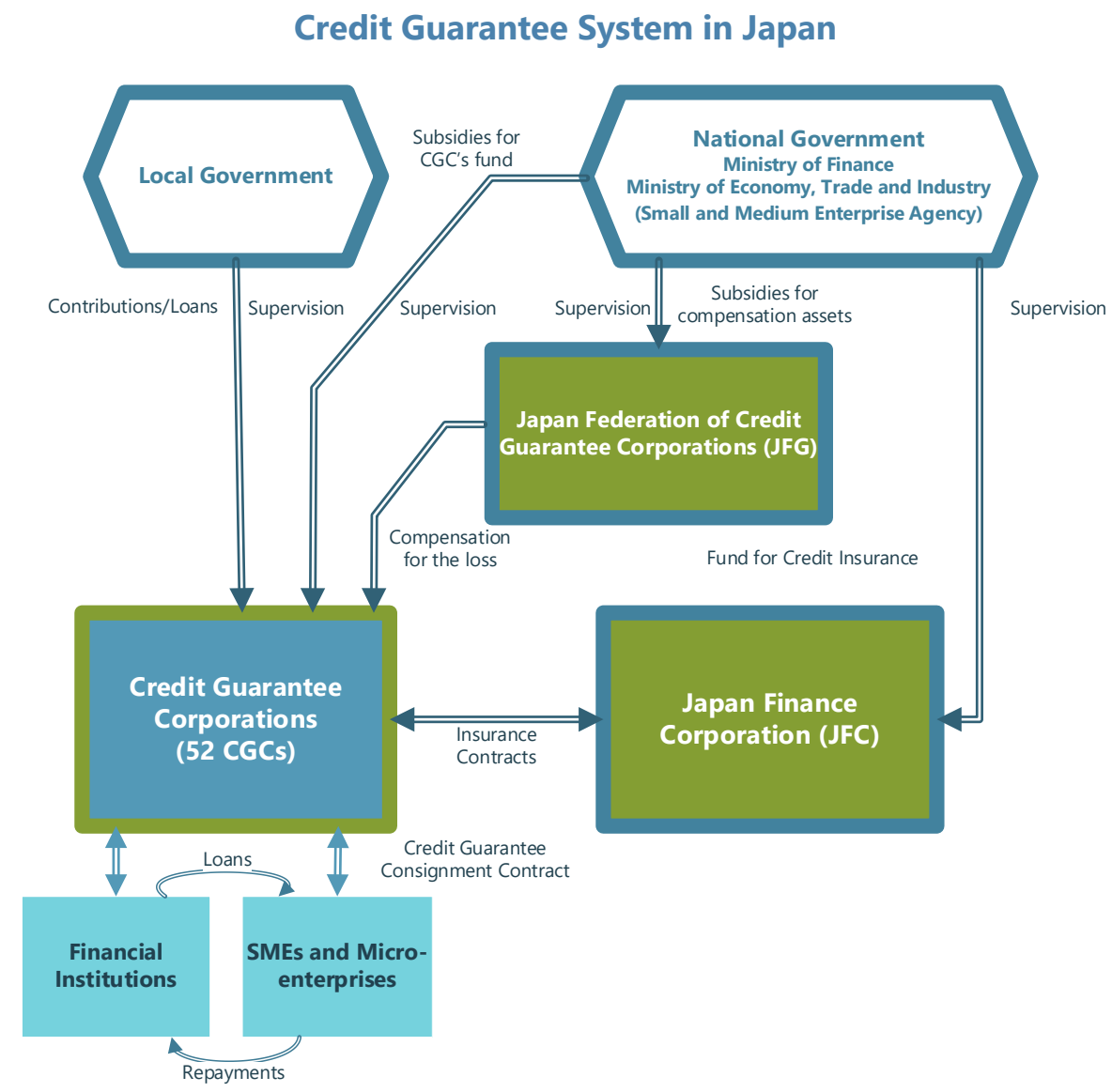

Source: Yamori (2015). 
Credit Guarantee Scheme before 2006. The credit guarantee program in Japan began in 1950, with the introduction of the Small and Medium-sized Enterprise Credit Insurance Act. The initial SME credit guarantee system in Japan consisted of two features: (i) risk-unrelated fixed guarantee fees; and (ii) a 100 percent guarantee when firms default. This overly generous credit scheme provided few incentives for financial institutions to screen and monitor loans, which in turn, gave rise to substantial moral hazard in the financial sector and contributed to the creation of zombie firms in Japan (Caballero et al. 2008).

\section{Reforms to Credit Guarantee Schemes with a Partial Guarantee and Risk-Related} Guarantee Fees. In 2005, the Japanese government introduced a sequence of reforms to increase risk-sharing by financial institutions. The reforms included two key elements including a risk-related guarantee-fee scheme and a partial guarantee of 80 percent. In 2006, a risk-related guarantee-fee scheme was introduced, where firms were categorized into nine different risk groups and guarantee fee rates were applied differentially to each risk group. In the following year, the so-called responsibility-sharing system was introduced with a partial guarantee method. Under this new system, CGCs were to cover up to 80 percent of each loan, where lender banks were to cover the rest of the incurred loss amount. The purpose of a partial guarantee scheme was to incentivize banks to better screen and monitor their borrowers by sharing the responsibility of loan default.

Emergency Credit Guarantee Program in 2008. The reform efforts were short-lived, however, as the Global Financial Crisis (GFC) of 2008 led to a sudden drop in demand, exacerbating financing conditions of the Japanese SMEs. In October 2008, the Japanese government introduced a large-scale new guarantee scheme, called the Emergency Credit Guarantee Program (ECGP). ${ }^{1}$ It comprised several features including: a 100 percent guarantee to SMEs and a prolonged duration of an ECG loan over 10 years, longer than the 7-year coverage applied to standard credit guarantee programs. In addition, credit guarantee fees applied to different risk groups were removed. Instead, a uniform and fixed rate fee of $0.75-0.80$ percent were applied to all firms, regardless of the riskiness. ${ }^{2}$

Revisions to the Credit Guarantee System in 2018. The recent reform of the credit guarantee system aims to increase risk-sharing responsibility by financial institutions while maintaining support for SMEs in the early stages of their business life cycle. The reform includes three main pillars: (i) higher risk-sharing between the CGCs and financial corporations with a lower guarantee coverage of 80 percent for loans under the largest program (i.e. Safety Net Program No. 5.); (ii) limiting the use of 100 percent guarantee as a safety net for the event of substantive crises; and (iii) maintaining 100 percent guarantee to start-ups and micro-businesses with an increased ceiling on the loan amount to facilitate business successions.

\footnotetext{
${ }^{1}$ This is one of the largest credit guarantee programs introduced by OECD countries, with planned guarantees amounting to $¥ 36$ trillion (about 7 percent of GDP) and actual guarantees amounting to $¥ 27$ trillion.

${ }^{2}$ According to a survey conducted by Yaomori (2015), the generous credit guarantee schemes were widely used by SMEs during the crisis, with many SMEs reporting that an increase in guarantee coverage and lower guarantee fees played an important role during the GFC economic downturn.
} 


\section{Annex 2. Policies to Promote Business Succession in Japan}

Firm managers are aging. Japan's population is rapidly shrinking, with the population expected to decline by 25 percent over the next 40 years. Owners of Japanese firms are also aging rapidly - the median age of owners of Japanese SMEs has increased by nearly 20 years over the past two decades, from 47 to 66 years old (see Figure below). Over the next decade, about 2.45 million SME owners are projected to be over 70 years old. It is inevitable that retiring managers will face the challenge of ensuring a smooth transition of their businesses to the next generation.

\section{Age of SME Business Owners in Japan}

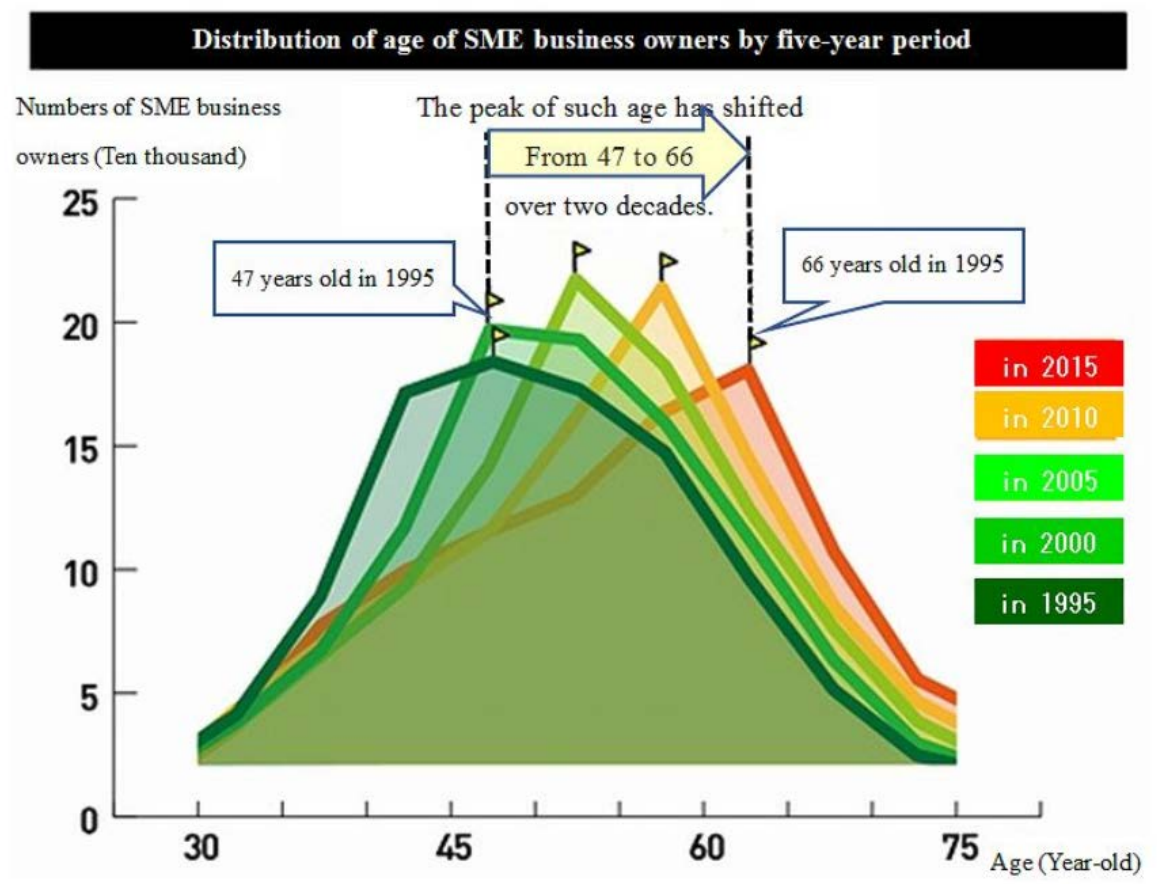

Source: METI

\section{Significant hurdles remain in ensuring a smooth handover of business from one} generation to the next generation in Japan. First, lack of preparation and awareness by incumbent managers on the issue of business succession is problematic. According to a survey conducted by METI, about thirty percent of incumbent managers of Japanese SMEs have not decided on a successor. Second, within-family succession is still the preferred and most common solution to many incumbent owners. According to the same survey, among SMEs that have decided on a business successor, which is about 42 percent of total Japanese SMEs, nearly two-thirds of the successors are found within the family.

Government policies are in place to facilitate business succession. To address these challenges, the Small and Medium Enterprise Agency (SMEA) of METI introduced a FiveYear Plan for Business Succession in July 2017 to reinforce efforts to support SMEs in their smooth business succession. This includes plans to expand prefecture-based networks to support management succession at small companies. The network comprises a group of 
various industry players and experts. It includes SMEs, credit guarantee corporations, prefectural and municipal government as well as chamber of commerce, and federations of small business associations. The main purpose of these networks is to raise awareness of business succession issues among SME owners and to facilitate business matching between SME business owners and candidates. Thus far, Business Transfer Support Centers have been set up in 47 prefectures for this very purpose.

In addition, tax reforms to facilitate smooth business succession are being considered. These reforms may be implemented as early as fiscal year 2019, to expand the tax deferral rates and to lower the conditions needed to benefit from such tax reforms. Several elements of the tax reforms considered by METI include:

- $\quad$ Improving tax system for business succession. A reduction and exemption of registration tax and real estate acquisition tax related to mergers and acquisitions (M\&A) is being considered, to encourage non-family successions (that have increased in recent years). Also, there is consideration being given to possibly expand the deferral of payment of inheritance tax and gift tax on non-listed firms from 53 percent to 100 percent, lowering the requirements so that more firms can take advantage of the change, and expanding the scope of companies eligible to use the system and promoting M\&A.

- Enhancing Financial Support. Providing low-interest loans to support succession (for instance, for M\&A or capital investment). 


\section{References}

Bank of Japan, 2018. Regional Economic Report, Tokyo (June).

Caballero, R., T. Hoshi and A. Kashyap, 2008. "Zombie Lending and Depressed

Restructuring in Japan,” American Economic Review, 98 (5), pp. 1943-77.

Calvo, José, 2006. “Testing Gibrat's Law for Small, Young and Innovating Firms," Small Business Economics, 26 (2), pp. 117-23.

Colacelli, Mariana and Emilio Fernandez-Corugedo, 2018. "Macroeconomic Effects of Japan's Demographics: Can Structural Reforms Reverse Them?” IMF Working Paper 18/248. International Monetary Fund, Washington DC.

Corrado, C. J. Haskel, C. Jona-Lasinio and M. Iommi, 2013. "Innovation and Intangible Investment in Europe, Japan, and the United States," Oxford Review of Economic Policy, 29 (2), pp. 261-86.

Corrado, C., J. Haskel, C. Jona-Lasinio and M. Iommi, 2016. "Intangible Investment in the EU and US Before and Since the Great Recession and its Contribution to Productivity Growth," EIB Working Papers, 2016/08, European Investment Bank.

Criscuolo, C., P. Gal, and C. Menon, 2014. "The Dynamics of Employment Growth: New Evidence from 18 Countries," CEP Discussion Paper, 1274, Center for Economic Performance.

Duval, R, G. Hong and Y. Timmer, 2017. "Financial Frictions and the Great Productivity Slowdown," IMF Working Paper 17/129. International Monetary Fund, Washington DC.

Gal, Peter, 2013. "Measuring Total Factor Productivity at the Firm Level using OECDORBIS,” Economics Department Working Papers No. 1049, OECD, Paris.

Gal, P. and A. Hijzen, 2016. "The Short-Term Impact of Product Market Reform: A CrossCountry Firm-Level Analysis,” IMF Working Paper 16/116. International Monetary Fund, Washington DC.

Haltiwanger, J. R. Jarmin and J. Miranda, 2013. "Who Creates Jobs? Small versus Large versus Young," Review of Economics and Statistics, 95 (2), pp. 347-61.

Heshmati, Almas, 2001. "On the Growth of Micro and Small Firms: Evidence from Sweden," Small Business Economics, 17 (3), pp. 221-28.

Hsieh, Chang-Tai and Peter Klenow, 2014. "The Life Cycle of Plants in India and Mexico," Quarterly Journal of Economics, 129 (3), pp. 1035-84.

International Monetary Fund, 2012. "Japan: Selected Issues," IMF Country Report No. 12/209, Washington DC. 
International Monetary Fund, 2013. "Japan: Article IV Consultation Staff Report," IMF Country Report No. 13/253, Washington DC.

International Monetary Fund, 2017a. "Gone with the Headwinds: Global Productivity," IMF Staff Discussion Note No. 17/04, Washington DC.

International Monetary Fund, 2017b. "Financial Sector Assessment Program, Japan," IMF Country Report No. 17/283, Washington DC.

International Monetary Fund, 2018a. "Productivity Growth in Asia: Boosting Firm Dynamism and Weeding out the Zombies," IMF Regional Economic Outlook: Asia and Pacific Background Paper No.3, Washington DC.

International Monetary Fund, 2018b. "Japan: Article IV Consultation Staff Report," IMF Country Report No. 18/333, Washington DC.

Kalemli-Özcan, S., B. Sorensen, Ca. Villegas-Sanchez, V. Volosovych and S. Yesiltas, 2015. "How to Construct Nationally Representative Firm Level data from the ORBIS Global Database," NBER Working Paper No. 21558.

Lam, R. and J. Shin, 2012. "What Role Can Financial Policies Play in Revitalizing SMEs in Japan?” IMF Working Paper 12/291, International Monetary Fund, Washington DC.

Lopez-Garcia, P. and S. Puente, 2012. "What Makes a High-Growth Firm? A Dynamic Probit Analysis using Spanish Firm-level Data," Small Business Economics, 39 (4), pp. 1029-41.

Jones, R. and Y. Jin, 2017. "Boosting Productivity for Inclusive Growth in Japan," OECD Economics Department Working Papers, No. 1414, OECD Publishing, Paris.

OECD, 2017. The Great Divergence(s), OECD Science, Technology and Innovation. Policy Papers, May 2017. No. 39.

Pagano, P. and F. Schivardi, 2003. "Firm Size Distribution and Growth," Scandinavian Journal of Economics, 105 (2), pp. 255-74.

Tsuruta, D., 2016. "SME Policies as a Barrier to Growth of SMEs," Paper prepared as part of the project "Study on Corporate Finance and Firm Dynamics," at the Research Institute of Economy, Trade and Industry (RIETI).

Zhou, Yixiao, 2016. "Drivers of Globalization of R\&D Investment by U.S. Multinational Enterprises: Evidence from Industry-Level Data," International Journal of Economics and Finance, 8 (2), pp. 51-69. 


\section{Appendix 1. Descriptive Statistics}

Japan: Descriptive Statistics on Orbis Dataset (2001-13)

\begin{tabular}{|c|c|c|c|c|c|c|}
\hline All & $\mathrm{N}$ & Mean & Median & p25 & p75 & SD \\
\hline labor productivity & 1,919, 104 & 12.22 & 12.19 & 11.53 & 12.85 & 1.05 \\
\hline labor productivity growth & $1,919,104$ & -1.98 & -0.02 & -0.17 & 0.12 & 0.30 \\
\hline Age & $1,273,859$ & 31.17 & 30.00 & 19.00 & 42.00 & 15.91 \\
\hline $\log$ (Total Assets) & $1,919,093$ & 14.65 & 14.58 & 13.28 & 15.91 & 2.01 \\
\hline Investment/Total Assets(\%) & $1,918,170$ & 26.74 & 21.74 & 7.80 & 40.83 & 23.79 \\
\hline Intangibles Investment/Total Investment (\%) & $1,484,486$ & 5.25 & 0.51 & 0.02 & 2.58 & 14.78 \\
\hline Number of Employees & $1,919,104$ & 33.33 & 11 & 5 & 29 & 69.21 \\
\hline Number of Unique Firms & 492,017 & & & & & \\
\hline SMES & $\mathrm{N}$ & Mean & Median & p25 & p75 & SD \\
\hline labor productivity & $1,795,836$ & 12.19 & 12.16 & 11.52 & 12.82 & 1.02 \\
\hline labor productivity growth & $1,795,836$ & -2.05 & -0.02 & -0.18 & 0.13 & 0.30 \\
\hline Age & $1,185,501$ & 30.40 & 29.00 & 18.00 & 41.00 & 15.50 \\
\hline $\log$ (Total Assets) & $1,795,825$ & 14.40 & 14.42 & 13.18 & 15.63 & 1.77 \\
\hline Investment/Total Assets(\%) & $1,794,925$ & 26.74 & 21.62 & 7.68 & 40.90 & 23.99 \\
\hline Intangibles Investment/Total Investment (\%) & $1,393,153$ & 5.06 & 0.46 & 0.00 & 2.38 & 14.65 \\
\hline Number of Employees & $1,795,836$ & 20.80 & 10.00 & 5.00 & 24.00 & 30.70 \\
\hline Number of Unique Firms & 444,413 & & & & & \\
\hline non-SMEs & $\mathrm{N}$ & Mean & Median & p25 & p75 & SD \\
\hline labor productivity & 123,268 & 12.71 & 12.69 & 11.92 & 13.31 & 1.35 \\
\hline labor productivity growth & 123,268 & -1.03 & -0.01 & -0.09 & 0.07 & 0.18 \\
\hline Age & 88,088 & 41.54 & 43.00 & 29.00 & 56.00 & 17.71 \\
\hline $\log ($ Total Assets) & 123,268 & 18.27 & 18.09 & 17.20 & 19.05 & 1.78 \\
\hline Investment/Total Assets(\%) & 123,245 & 26.82 & 23.16 & 9.66 & 39.85 & 20.68 \\
\hline Intangibles Investment/Total Investment (\%) & 91,333 & 8.15 & 1.61 & 0.48 & 6.32 & 16.36 \\
\hline Number of Employees & 104,084 & 249.53 & 194 & 131 & 335 & 147.43 \\
\hline Number of Unique Firms & 47,604 & & & & & \\
\hline
\end{tabular}

Source: ORBIS.

Notes: $\mathrm{N}$ denotes the number of observations; $\mathrm{p} 25$ denotes the $25^{\text {th }}$ percentile; $\mathrm{p} 75$ denotes the $75^{\text {th }}$ percentile; SD denotes standard deviation. 


\section{Appendix 2. SME Definition}

\section{Official SME Definition by Sector in Japan}

\begin{tabular}{c|cc} 
& \multicolumn{2}{c}{ SMEs } \\
\hline Business Type & \multicolumn{2}{c}{ Stated capital or number of employee } \\
\hline Manufacturing Industry and Others & 300 million yen or less & 300 or fewer \\
Wholesale Trade Industry & 100 million yen or less & 100 or fewer \\
Service Industry & 50 million yen or less & 100 or fewer \\
Retail Trade Industry & 50 million yen or less & 50 or fewer \\
\hline
\end{tabular}

Source: White Paper on Small and Medium Enterprises in Japan, Ministry of Economy, Trade and Industry, 2018. 